\title{
KAJIAN HUKUM TERHADAP REPRESENTASI KEPEMIMPINAN WANITA SEBAGAI WUJUD BIROKRASI YANG PROFESIONAL
}

\author{
Riski Febria Nurita \\ Fakultas Hukum Universitas Merdeka Malang \\ Jl. Terusan Dieng No. 62-64; Malang; 65146; Indonesia; (0341) 580161 \\ riski.febria@unmer.ac.id
}

\begin{abstract}
Convention on the Elimination of All Forms of Discrimination Against Women 1979, has ratified Indonesia as the Law of the Republic of Indonesia Number 7 Year 1984 About Ratification of the Convention Concerning the Elimination of All Forms of Discrimination Against Women. In relation to the ratification of the Convention on Women, among others, means to promote the widest possible extent of women's rights, Indonesia guarantees for women, on equal terms with men, to protect their rights. This research focuses on legal studies related to the impact of the ratification in realizing the contribution of women's role in contribution. The method used is the approach of law and case approach to solve the problem of women's leadership representation as a professional bureaucracy after Indonesia ratified the women's convention. The form of implementation of the law which is the ratification of the international women convention is not implemented in every life of the nation and state, there are still many misuse and injustice to the role of women in bureaucracy in Indonesia. The ratification requires the government to prioritize the right of women as leaders to realize a professional bureaucracy.
\end{abstract}

Keywords: Bureaucracy, Discrimination, Gender, Women's Leadership, Professional.

\begin{abstract}
Abstrak
Convention on the Elimination of All Forms of Discrimination Against Women 1979, telah meratifikasi Indonesia menjadi Undang-Undang Republik Indonesia Nomor 7 Tahun 1984 Tentang Pengesahan Konvensi Mengenai Penghapusan Segala Bentuk Diskriminasi Terhadap Wanita. Berkaitan dengan ratifikasi Konvensi Perempuan ini antara lain berarti mempromosikan seluas mungkin hak-hak perempuan, Indonesia menjamin bagi wanita, atas dasar persamaan dengan pria, untuk terlindungi hak-haknya. Penelitianan ini mefokuskan pada kajian hukum berkaitan dengan dampak ratifikasi tersebut dalam mewujudkan kontribusi peran perempuan dalam kontribusi Metode yang digunakan adalah pendekatan undang-undang dan pendekatan kasus untuk menyelesaikan permasalah terhadap representasi kepemimpinan wanita sebagai wujud birokrasi yang profesional setelah Indonesia meratifikasi konvensi perempuan tersebut. Bentuk pelaksanaan dari undangundang yang merupakan ratifikasi konvensi perempuan internasional tersebut tidak dilaksanakan dalam setiap kehidupan bangsa dan negara, masih banyak penyalahgunaan dan ketidak adilan terhadap peran perempuan dalam birokasi di Indonesia. Ratifikasi tersebut mengharuskan pemerintah mengutamakan hak perempuan sebagai pemimpin untuk mewujudkan birokasi yang profesional.
\end{abstract}

Kata Kunci: Birokrasi, Diskriminasi, Gender, Kepemimpinan Wanita, Profesional. 


\section{Pendahuluan}

Gender merupakan hasil sosialisasi dan enkulturasi seseorang atau Gender merupakan hasil konstruksi sosial yang terdiri dari sifat, sikap dan perilaku seseorang pelajari. Gender mempelajari berbagai sifat dan perilaku yang dianggap pantas bagi dirinya karena ia berjenis kelamin perempuan atau laki-laki. Sifat-sifat seperti "feminitas" bagi perempuan dan "maskulinitas" bagi laki-laki ditentukan oleh lingkungan budayanya (Ihromni, 2000). Keseimbangan gender merupakan isu global dan bagaimana menyikapi peran dari isu gender tersebut. Peran gender tersebut merupakan pencerminan dari suatu budaya bangsa yang meberikan keadilan gender. Bahwasanya tiap bangsa yang berbudaya dan beradab dalam menegakkan sistem kenegaraannya selalu berdasarkan suatu sistem filsafat atau sistem ideologi yang terjabar dan ditegakkan dalam konstitusi negara (Nurita, 2015). Bagaimana identitas dan integritas sistem kenegaraannya itu, memancarkan ajaran dan nilai fundamental sistem filsafat dan atau sistem ideologi negaranya.

Gender sebagai konsep yang mengacu pada peran dan tanggung jawab laki-laki dan perempuan yang terjadi akibat dari dan dapat berubah oleh keadaan sosial dan budaya masyarakat (Mu'awanah, 2006). Peran gender dengan demikian adalah pembagian kerja antara perempuan dan laki-laki. Di Indonesia, ditetapkan sebagai laki-laki adalah kepala keluarga dan pencari nafkah utama, perempuan adalah ibu rumah tangga dan tugas utamanya adalah mendidik dan mengasuh anak.Konsekuensi dari ketentuan pembagian seperti tersebut di atas adalah, bahwa peran perempuan adalah di ranah domestik, peran gender laki-laki adalah di wilayah publik (Ihromni, 2000). Kesetaraan gender merupakan amanat dari Undang-Undang Dasar Republik Indonesia tahun 1945.

Gender adalah suatu sifat yang melekat baik pada laki-laki maupun perempuan yang dikons- truksi atau dibentuk secara sosial maupun kultural dengan akibat terjalinnya hubungan sosial yang membedakan fungsi, peran dan tanggung jawab kedua jenis kelamin (Mochtar, Indrayanti, \& Ristanty, 2013).

Perbedaan pada peran gender dapat menciptakan suatu sistem ketidakadilan gender yang kemudian diterima meluas, dianggap sesuatu yang biasa, dan tidak lagi dirasakan sebagai sesuatu yang salah, sehingga perlu disadari juga bahwa meskipun gender dapat diubah, harus ada usaha khusus untuk mengubahnya karena merupakan kebiasaan yang sudah diterima luas (Ihromni, 2000). Kendala-kendala optimalisasi perempuan sebenarnya berkaitan dengan 4 hal, diantaranya yaitu Interpretasi keagamaan, Struktur Sosial, Perempuan sebagai kelompok minoritas dan Isu Gender dalam masyarakat (Mu'awanah, 2006).

1. Interpretasi keagamaan, misalnya saja melalui ayat-ayat al-qur'an dan hadits contohnya seperti firman Allah dalam (QS. An Nisaa' (4):34):

"Kaum laki-laki itu adalah pemimpin bagi kaum wanita, oleh karena Allah telah melebihkan sebahagian mereka (laki-laki) atas sebahagian yang lain (wanita), dan karena mereka (laki-laki) telah menafkahkan sebagian dari harta mereka. Sebab itu maka wanita yang saleh, ialah yang taat kepada Allah lagi memelihara diriketika suaminya tidak ada, oleh karena Allah telah memelihara (mereka) Wanitawanita yang kamu khawatirkan nusyuznya, maka nasehatilah mereka dan pisahkanlah mereka di tempat tidur mereka, dan pukullah mereka. Kemudian jika mereka mentaatimu, maka janganlah kamu mencaricari jalan untuk menyusahkannya. Sesungguhnya Allah Maha Tinggi lagi Maha Besar".

Contoh lain, yaitu dari hadits Rasullullah SAW: "Tidak akan Berjaya suatu kaum kalau menyerahkan urusan kepada perempuan"

2. Struktur Sosial, Posisi perempuan masih dihadapkan dengan posisi laki-laki. Budaya patriakhi memposisikan perempuan pada peran-peran 


\section{Kajian Hukum terhadap Representasi Kepemimpinan Wanita sebagai Wujud Birokrasi yang Profesional Riski Febria Nurita}

domestik seperti peran pengasuhan, pendidik, dan penjaga moral (Sihite, 2007). Sementara posisi laki-laki sering dikaitkan dengan lingkungan publik, yang berhubungan dengan urusan luar rumah. Perempuan yang ingin di ranah publik sulit melepaskan diri dari tanggung jawab lingkungan domestik. Perempuan kurang berdaya untuk menghindar dari beban ganda tersebut sebagai pengasuh anak sudah merupakan persepsi budaya secara umum. Kontrol Budaya agaknya lebih ketat terhadap perempuan dari pada laki-laki.

3. Perempuan sebagai kelompok minoritas, Adanya relativitas bahwa posisi lemah

4. Perempuan di dalam masyarakat kurang disadari oleh kaum perempuan sendiri. Bahkan tidak jarang kelompok perempuan merasa senang padahal kelompok lain prihatin. Terhadap suatu fenomena sekelompok perempuan mensahkannya tetapi kelompok lainnya masih menganggapnya sebagai sesuatu yang wajar. (Mu'awanah, 2006)

5. Isu Gender

a. Gender dan Subordinasi

Pandangan gender ternyata bisa menimbulkan subordinasi terhadap perempuan. Anggapan bahwa perempuan itu irrasional atau emosional sehingga perempuan tidak bisa tampil memimpin, berakibat munculnya sikap yang menempatkan perempuan pada posisi yang tidak penting (Fakih, 2007).

b. Gender dan Stereotipe Secara umum stereotipe adalah pelabelan atau penandaan terhadap suatu kelompok tertentu. Celakanya suatu stereotipe selalu merugikan dan menimbulkan ketidakadilan (Fakih, 2007). Misalnya penandaan yang berawal dari asumsi bahwa perempuan bersolek adalah dalam rangka memancing perhatian lawan jenisnya, maka setiap ada kekerasan dan pelecehan, masyarakat berkecenderungan menyalahkan korbannya.

c. Gender dan Kekerasan

Kekerasan (Violence) adalah serangan atau invasi (assault) terhadap fisik maupun integritas mental psikologis seseorang. Kekerasan yang disebabkan oleh bias gender yaitu ini disebut gender-related violence.

d. Gender dan Beban Kerja

Adanya anggapan bahwa kaum perempuan memiliki sifat memelihara dan rajin, serta tidak cocok untuk menjadi kepala rumah tangga mengakibatkan bahwa semua pekerjaan domestik rumah tangga menjadi tanggung jawab perempuan. Terlebih-lebih jika perempuan tersebut harus bekerja, maka ia memikul beban kerja ganda.

Menurut Khofifah (mantan menteri Pemberdayaan Perempuan) ada tiga faktor yang menjadi lemahnya kedudukan dan peran perempuan sebagai berikut: Faktor Budaya, berupa gagasan sosial budaya dalam bentuk gender stereotipe yang kurang menguntungkan perempuan. Demikian pula etika politik yang belum transparan, sehingga belum menjamin kesempatan bagi perempuan untuk mendapatkan kedudukan dan peran yang seimbang dengan kaum laki-laki. Faktor Struktur Kelembagaan, yang kurang memberikan kemudahan akses bagi perempuan. Faktor Individual, yaitu kaum perempuan sendiri sebagian besar perempuan Indonesia masih rendah tingkat pendidikannya, kurang percaya diri dan yang lebih menentukan adalah aspek ekonomi, yaitu banyak keluarga yang menentukan posisi marginal bagi sebagian besar perempuan di Indonesia (Mu'awanah, 2006).

Sebenarnya Undang-Undang Dasar Republik Indonesia tahun 1945 yang dirumuskan pada tahun 1945 sejak semula telah mencantumkan dalam Pasal 27 (1), bahwa semua orang mempunyai kedudukan 
yang sama di muka hukum. Jadi sejak tahun 1945 di negara Indonesia prinsip kesetaraan pria dan wanita di depan hukum telah diakui. Dilihat pula pada Pasal 27 (2) bahwa tiap-tiap warga negara berhak atas pekerjaan dan penghidupan yang layak bagi kemanusiaan, sehingga dalam pasal ini baik pria maupun wanita memiliki hak yang sama atas pekerjaan dan memiliki hak yang sama pula atas penghidupannya yang layak tanpa adanya diskriminasi.

Selain itu pada tanggal 10 Desember 1948 bangsa-bangsa di dunia sepakat pada tanggal 10 Desember 1948 sepakat untuk menyatakan bahwa: "Setiap manusia dilahirkan merdeka dan sama dalam martabat dan hak-haknya" melalui Universal Declaration Of Human Rights 1948. Selain DUHAM pada tahun 1979 Konvensi mengenai Penghapusan Segala Bentuk Diskriminasi terhadap Wanita diterima oleh negara-negara anggota PBB berdasarkan suatu pertimbangan hukum, bahwa diskriminasi terhadap wanita merupakan pelanggaran terhadap asas-asas persamaan hak dan rasa hormat terhadap martabat manusia (Ihromni, 2000).

Konvensi wanita tersebut yang dikenal dengan Convention on the Elimination of All Forms of Discrimination Against Women 1979, Indonesia meratifikasi konvensi wanita ini menjadi UndangUndang Republik Indonesia Nomor 7 Tahun 1984 Tentang Pengesahan Konvensi Mengenai Penghapusan Segala Bentuk Diskriminasi Terhadap Wanita. Penting untuk disadari bersama, bahwa dengan meratifikasi suatu Konvensi Internasional, negara yang bersangkutan selain wajib untuk membuat undang-undang, hukum dan aturanaturan yang sesuai isi konvensi yang diratifikasi, negara juga mengadakan berbagai usaha yang bertujuan memasyarakatkan dan menerapkan seluas mungkin isi konvensi yang telah diratifikasi. Berkaitan dengan ratifikasi Konvensi Perempuan ini antara lain berarti mempromosikan seluas mungkin hak-hak perempuan Indonesia.
Berikut ini dikemukakan beberapa hal yang mendapat perhatian dan pengaturan dalam konvensi tersebut khususnya dalam bidang pemerintahan antara lain Pasal 7 yang menyatakan bahwa Negara-negara peserta wajib melakukan langkahtindak yang tepat untuk menghapus diskriminasi terhadap wanita dalam kehidupan politik dan kehidupan kemasyarakatan di negaranya, khususnya menjamin bagi wanita, atas dasar persamaan dengan pria,

Hak-hak yang diatur antara lain: (a) untuk memberikan suara dalam semua pemilihan umum dan jajak pendapat publik dan dapat dipilih dalam pemilihan untuk semua lembaga berdasarkan pemilihan umum. (b) untuk berpartisipasi dalam perumusan kebijakan pemerintah dan implementasinya, memegang jabatan dalam pemerintahan dan melaksanakan segala fungsi pemerintahan di semua tingkat (c) untuk berpartisipasi dalam organisasi-organisasi dan perkumpulan-perkumpulan non-pemerintah yang berhubungandengan kehidupan masyarakat dan politik negara.

Berdasarkan latar belakang yang telah disampaikan diatas penelitian ini memfokuskan pada kajian hukum terhadap representasi kepemimpinan wanita dalam mewujudkan birokrasi yang profesional di indonesia menimbulkan beberapa persoalan diantaranya bagaimana kajian hukum terhadap representasi kepemimpinan wanita sebagai wujud birokrasi yang profesional di Indonesia, apa saja partisipasi dari Pemerintah Indonesia untuk turut serta dalam peningkatan representasi kepemimpinan yang dipegang oleh wanita sebagai wujud birokrasi yang profesional di Indonesia.

\section{Metode}

Penelitian ini menggunakan pendekatan penelitian Normatif dengan pendekatan melalui analisa terhadap peraturan-peraturan dalam hukum Nasional dan Internasional (statue approach) 


\section{Kajian Hukum terhadap Representasi Kepemimpinan Wanita sebagai Wujud Birokrasi yang Profesional Riski Febria Nurita}

dan juga menggunakan studi kasus (case study) mengenai representasi kepemimpinan wanita dalam birokrasi di Indonesia yang sudah ada. Secara normatif berarti penelitian hukum meletakkan hukum sebagai sebuah bangunan sistem norma. Sistem norma yang dimaksud adalah mengenai asas-asas, norma, kaidah, dan peraturan perundang-undangan, putusan pengadilan, perjanjian serta doktrin (ajaran) (Fajar, 2010). Peter Mahmud Marzuki (2005) menjelaskan penelitian hukum normatif adalah suatu proses untuk menemukan suatu aturan hukum, prinsip-prinsip hukum, maupun doktrin-doktrin hukum untuk menjawab permasalahan hukum yang dihadapi. Analisis untuk mengetahui mengenai bagaimana representasi kepemimpinan wanita dalam mewujudkan birokrasi yang profesional di Indonesia.

Bahan hukum yang terdiri atas peraturan perundang-undangan hukum Nasional yang bersangkutan dengan penelitian. Penelitian menggunakan bahan hukum berupa undang-undang yaitu:

a. Undang-Undang Dasar republic Indonesia Tahun 1945;

b. Undang-Undang Republik Indonesia Nomor 7 Tahun 1984 Tentang Pengesahan Konvensi Mengenai Penghapusan Segala Bentuk Diskriminasi Terhadap Wanita;

c. Undang-Undang Republik Indonesia Nomor 39 Tahun 1999 Tentang Hak Azazi Manusia;

d. Konvensi Committee on the Elimination of all forms of Discrimination Against Women;

Bahan hukum yang terdiri atas buku atau jurnal hukum yang berisi mengenai prinsip-prinsip dasar (asas hukum), pandangan para ahli hukum (doktrin), hasil penelitian hukum, kamus hukum, dan ensiklopedia hukum (Fadjar, 2010). Dalam hal ini penelitian menggunakan beberapa literatur buku-buku mengenai Gender dan buku penunjang lainnya.

\section{Pembahasan}

\section{Kondisi Representasi Kepemimpinan Wanita Dalam Mewujudkan Birokrasi yang Profesional di Indonesia}

Kondisi gender di Indonesia sungguh memprihatinkan hal tersebut dapat dilihat dari hasil Human Development Index (HDI) atau Indeks Pembangunan Manusia dari 173 negara Indonesia berada pada peringkat 102 hal terebut berbeda dengan yang adan di negara Malaysia dan Singapura yang menduduki peringkat 53 dan 34 dari 173 negara. Kaitannya dengan kepemimpinan atau Leadership kondisi gender meprihatinkan pula di Indonesia sebenarnya disebabkan oleh beberapa hal diantaranya:

1. Faktor keagamaan, dimana seringkali interpretasi dari sebagian besar masyarakat di Indonesia melalui hadits dari rasulullah dan ayat dalam Al-Qur'an hanya dilihat dari luar saja tanpa mencari makna dibaliknya, misalnya saja hadits rasullulah yang berbunyi "Tidak akan Berjaya suatu kaum kalau menyerahkan urusan kepada perempuan", padahal apabila melihat hadits ini terjadi pada saat tertentu yaitu pada saat Putri Kisra menjabat kepala negara Persia dan menyobek surat yang dikirim rasulullah kepadanya lalu berdoa agar Allah menghancurkan kerajaan itu sehancur-hancurnya. Bahkan dilain waktu terdapat pula hadits dari Rasulullah "Serahkan sesuatu pada ahlinya, urusan dunia yang lebih tahu" dari hadits ini dapat mengetahui bahwa bukan hanya laki-laki saja yang ahli dalam suatu bidang namun juga perempuan, apabila perempuan lebih ahli dan lebih mampu dalam suatu hal maka mengapa tidak bila perempuan diangkat sebagai pemimpin dalam suatu bidang.

2. Faktor kultural, dimana budaya patriakhi telah lama berakar di Indonesia sehingga memposisikan perempuan pada peran-peran domestik saja misalnya ibu rumah tangga, pengasuh 
anak sedangkan laki-laki pada posisi pencari nafkah sehingga tidak dalam lingkup domestik, laki-laki dapat berkembang di luar sesuai dengan apa yang dia inginkan.

Sebenarnya masih banyak faktor-faktor yang lainnya hal-hal itulah yang menyebabkan terjadinya subordinasi dan stereotipe terhadap perempuan. Gender Management System adalah suatu pendekatan pada pengarus utamaan gender, yang merupakan jaringan terpadu dari struktur, mekanis dan proses yang dijadikan kedalam satu alur berpikir untuk menuntun, merencanakan, dan mengevalusi proses (apakah itu didalam membuat suatu kebijakan atau program) dari pengarusutamaan gender atau gender mainstreaming kedalam seluruh area kerja organisasi. GMS bertujuan untuk memajukan gender equality dan equity lewat mempromosisikan kemauan politik, meningkatkan kerjasama antar pemerintah dan non pemerintah dapat bekerja sama untuk menyelesaikan masalah kekerasan terhadap perempuan: membangun kapasitas dan berbagi pengalaman baik dalam menangani kekerasan terhadap perempuan. (Mochtar et al., 2013) apalagi apabila dikaitkan dengan kepemimpinan wanita yang menjabat dalam suatu birokrasi maka banyak sekali yang melabelkan bahwa wanita tersebut tidak mampu memimpin dan lemah hal inilah yang menimbulkan ketidak adilan gender di negara Indonesia.

Konstitusi Undang-Undang Dasar Negara Republik Indonesia Tahun 1945 pada Pasal 28 D Ayat (3) telah menjamin bahwa: "Setiap warga negara berhak memperoleh kesempatan yang sama dalam pemerintahan" Apabila melihat bahwa setiap warga negara adalah baik laki-laki maupun perempuan memperoleh kesempatan yang sama dalam pemerintahan, otomatis baik laki-laki maupun perempuan mendapat kesempatan yang sama menduduki jabatan dalam pemerintahan dengan kata lain dalam birokrasi di negara tanpa adanya diskriminasi. Contohnya dalam hal menduduki jabatan struc- tural (eselonisasi). Secara normatif, setiap PNS, baik laki-laki maupun perempuan memiliki peluang yang sama asal memenuhi beberapa kriteria yang telah ditentukan. Namun,pada kenyataannya hanya sedikit PNS perempuan yang dapat mencapai karier tertinggi rupanya perempuan terganjal budaya birokrasi yang tidak memihak kepadanya, misalnya saja tugas kodrati perempuan seperti hamil dan melahirkan maka akan menganggu tugas jabatan. Kesenjangan gender dalam Aparatur Pemerintah di Indonesia dapat lihat pada tabel di bawah ini:

Tabel. 1

\begin{tabular}{lllll}
\hline \multirow{2}{*}{ PNS } & \multicolumn{2}{l}{ PEREMPUAN } & \multicolumn{2}{l}{ LAKI-LAKI } \\
\hline \multirow{2}{*}{ Esselon Ia-IIIb } & JUMLAH & $\mathbf{0}$ & JUMLAH & $\mathbf{0}$ \\
\cline { 2 - 5 } Esselon Iva-Vb & 1883 & 6,98 & 25.110 & 93,02 \\
& 35.796 & 14,80 & 206.055 & 85,20 \\
\hline
\end{tabular}

Sumber: Harsuko Riniwati, Mendongkrak Motivasi dan Kinerja Pendekatan Pemberdayaan SDM hlm,27

Dapat dibayangkan apabila kepemimpinan dalam birokrasi lebih banyak di dominasi oleh lakilaki maka perumusan kebijakannya nantinya pun akan sesuai dengan kondisi dan pemikiran lakilaki, lalu apakah mereka akan memikirkan ranahranah kepentingan wanita?, misalnya saja mengenai AKI (Angka Kematian Ibu), Kesehatan Reproduksi Wanita, Program KB (Keluarga Berencana) dikaitkan dengan kawin muda yang saat ini marak terjadi di Indonesia. Saat ini Angka Kematian Ibu di Indonesia tertinggi di ASEAN, dapat di lihat pada tabel dibawah ini:

\section{Tabel 2}

\begin{tabular}{ll}
\hline Negara Asean & Jumlah AKI \\
\hline Indonesia & 58 per hari \\
Vietnam & 6 per hari \\
Philipina & 2 per hari \\
Thailand & 2 per hari \\
Malaysia & 1 per 1,25 hari \\
Singapura & 1 per $1 / 3$ hari \\
\hline
\end{tabular}

Sumber: Harsuko Riniwati, Mendongkrak Motivasi dan Kinerja Pendekatan Pemberdayaan SDM hlm, 24 


\section{Kajian Hukum terhadap Representasi Kepemimpinan Wanita sebagai Wujud Birokrasi yang Profesional Riski Febria Nurita}

Berdasarkan tabel berbanding belum mencerminkan pemanfaatan peran gender di Indonesia. Indonesia telah meratifikasi Convention on the Elimination of All Forms of Discrimination Against Women dengankeluarnya Undang-Undang Nomor 7 Tahun 1984 Tentang Pengesahan Konvensi Mengenai Penghapusan Segala Bentuk Diskriminasi Terhadap Wanita, dimana dalam UndangUndang ini jaminan dan perlindungan terhadap wanita sangat dijunjung tinggi misalnya saja didalam bidang politik, sosial budaya, bidang hukum, kesehatan. Perlu diingat bahwa dengan meratifikasi suatu konvensi Internasional, negara yang bersangkutan wajib mengadakan berbagai usaha yang bertujuan mengimplementasikan segala ketentuan yang ada dalam konvensi yang telah diratifikasi tersebut. Namun yang terjadi Indonesia belum sepenuhnya mengimplementasikan segala ketentuan yang ada dalam undang-undang tersebut sehingga diskriminasi gender masih terus berlanjut sampai saat ini.

\section{Partisipasi Pemerintah dalam Pengaturan Hukum Terhadap Kepemimpinan Wanita Sebagai Wujud Birokrasi yang Profesional}

Birokrasi merupakan alat kekuasaan bagi yang dapat menguasainya, birokrasi menjalankan penyelenggaraan negara sehingga harus dijamin netralitasnya. Ada beberapa fungsi dari birokrasi itu sendiri diantaranya:

1. Memberi advice kepada minister;

2. Mengelola Sumber Daya Government;

3. Membuat keputusan;

4. Menjalani hari-hari administrasi;

Oleh karena hal-hal tersebut merupakan fungsi yang sangat central di negara, maka diperlukan penilaian atau pengukuran kinerja dari suatu Birokrasi. Penilaian kinerja sangat penting karena dapat digunakan sebagai ukuran keberhasilan suatu organisasi dalam mencapai misinya.
Ada beberapa indikator yang biasanya digunakan untuk mengukur kinerja birokrasi publik, yaitu sebagai berikut (Agus Dwiyanto, 2006):

1. Produktivitas

Konsep produktivitas tidak hanya mengukur tingkat efisiensi tetapi juga efektivitas pelayanan. General Accounting Office (GAO) mengembangkan suatu ukuran produktivitas dengan memasukkan seberapa besar pelayanan publik itu memiliki hasil yang diharapkan sebagai salah satu indikator kinerja yang penting.

2. Kualitas Layanan

Kepuasan masyarakat terhadap layanan dapat dijadikanindikator kinerja organisasi publik.

3. Responsivitas

Kemampuan organisasi untuk mengenali kebutuhan masyarakat, menyusun agenda dan prioritas pelayanan, dan mengembangkan program-program pelayanan publik sesuai dengan kebutuhan dan aspirasi masyarakat. Secara singkat responsivitas di sini menunjuk pada keselarasan antara program dan kegiatan pelayanandengan kebutuhan aspirasi masyarakat.

4. Responsibilitas

Menjelaskan apakah pelaksanaan kegiatan organisasi publik itu dilakukan sesuai dengan prinsip-prinsip administrasi yang benar atau sesuai dengan kebijakan organisasi.

5. Akuntabilitas

Konsep akuntabilitas publik dapat digunakan untuk melihat seberapa besar kebijakan dan kegiatan organisasi publik itu konsisten dengan kehendak masyarakat banyak.

Perlibatan hampir seluruh warga polis dalam proses penataan negara ini belum melahirkan suasana kebebasan dan kesamaan yang menyeluruh bagi seluruh warga negara Yunani purba pada waktu itu. Hal ini terbukti dengan masih adanya diskriminasi politik yang meminggirkan hak kaum perempuan dan kalangan budak, maupun anakanak (Nurtjahjo, 2006, 45). Perempuan dan budak 
dianggap tidak memiliki hak dalam partisipasi politikpengelolaan negara. Mereka tidak memiliki kebebasan yang penuh dan tidak dipandang sama statusnya baik dihadapan hukum maupun' pemerintahan bersama'waktu itu. Namun demikian, nilai kebebasan dan kesamaan (persamaan) hak mengeluarkan pendapat itu dipraktikkan secara relatif baik pada seluruh warga polis yang dewasa, walaupun ada pengecualian bagi perempuan dan budak (Mochtar et al., 2013).

Birokrasi yang profesional dapat terwujud apabila di dalamnya terdapat beberapa keahlian khusus yang melekat bukan hanya keahlian khusus saja namun juga penguasaan-penguasaan terhadap bidangnya. Namun pada kenyataannya acapkali pembedaan terhadap laki-laki dan perempuan melahirkan peran gender yaitu pembagian tugas yang lebih banyak merugikan salah satu jenis kelamin khsusunya perempuan dimasyarakat. Sebagai contoh potensi dan bakat yang dimiliki perempuan kurang mendapatkan wadahnya, perempuan tidak bisa berkembang karena hanya diberi peran dalam urusan rumah tangga dan tidak diberi kesempatan serta peluang untuk peranperan yang produktif (Mochtar et al., 2013). Tanggung jawab seorang profesional menurut Wawan Setiawan, paling tidak harus bertanggung jawab kepada (Wahid, 2009):

1. Klien dan masyarakat yang dilayaninya;

2. Sesama profesi dan kelompok profesinya;

3. Pemerintah dan Negraanya.

Rapat gabungan PENGDA INI Jateng dan DIY disebutkan bahwa seorang profesional itu haruslah memiliki kepribadian sosial, sebagaimana berikut (Wahid, 2009):

1. Bertanggung jawab atas semua tindakannya;

2. Berusaha selalu meningkatkan ilmu pengetahuannya;

3. Menyumbangkan pikiran untuk memajukan keterampilan/kemahiran dan keahlian serta pengetahuan profesi;
4. Menjunjung tinggikepercayaan orang lain terhadap dirinya;

5. Menggunakan saluran yang baik dan benar serta legal dan halal untuk menyatakan ketidakpuasannya;

6. Kesediaan bekerja untuk kepentingan asosiasi/ organisasi dan senantiasa memenuhi kewajiban organisasinya;

7. Mampu bekerja dengan baik dan benar tanpa pengawasan tetap atau terus-menerus;

8. Mampu bekerja tanpa pengarahan terperinci;

9. Tidak mengorbankan orang lain / pihak lain demi kemajuan/keuntungan diri pribadinya semata-mata;

10. Setia pada profesi dan rekan seprofesi;

11. Mampu menghindari desas-desus;

12. Merasa bangga pada profesinya;

13. Memiliki motivasi penuh untuk lebih mengutamakan kepentingan masyarakat yang dilayaninya;

14. Jujur,tahu akan kewajiban dan menghormati hak pihak/orang lain;

15. Segala pengalamannya senantiasa diniati dengan niat dan itikad yang baik, tujuan yang dicapai hanya tujuan yang baik, demikian pula tata cara mencapai tujuan itu juga dengan cara yang baik.

Sehingga apabila ditarik beberapa pemahaman bahwa birokrasi yang profesional haruslah memenuhi unsur-unsur yang telah disebutkan di atas sehingga kinerja maupun tugas-tugas pelayanan yang dilakukan oleh birokrasi di Indonesia senantiasa berjalan profesional dan selalu mengedepankan pelayanan publik yang baik kepada masyarakat.

Undang-Undang Dasar tahun 1945 telah mencantumkan dalam Pasal 27 (1), bahwa semua orang mempunyai kedudukan yang sama di muka hukum. Jadi sejak tahun 1945 di negara Indonesia prinsip kesetaraan pria dan wanita di depan hukum telah diakui. Di lihat pula pada Pasal 27 (2) bahwa 
tiap-tiap warga negara berhak atas pekerjaan dan penghidupan yang layak bagi kemanusiaan, sehingga dalam pasal ini baik pria maupun wanita memiliki hak yang sama atas pekerjaan dan memiliki hak yang sama pula atas penghidupannya yang layak tanpa adanya diskriminasi.

Pasal 28 D ayat (3) amandemen kedua yaitu "Setiap warga negara berhak memperoleh kesempatan yang sama dalam pemerintahan". Serta dalam UndangUndang Republik Indonesia Nomor 39 Tahun 1999 Tentang Hak Asasi Manusia dalam Bagian Kedelapan mengenai Hak Turut Serta dalam Pemerintahan:

\section{Pasal 43}

(1) Setiap warga negara berhak untuk dipilih dan memilih dalam pemilihan umum

Berdasarkan persamaan hak melalui pemungutan suara yang langsung, umum, bebas, rahasia, jujur, dan adil sesuai dengan ketentuan peraturan perundang-undangan.

(2) Setiap warga negara berhak turut serta dalam pemerintahan dengan langsung atau dengan perantaraan wakil yang dipilihnya dengan bebas, menurut cara yang ditentukan dalam peraturan perundang-undangan. (3) Setiap warga negara dapat diangkat dalam setiap jabatan pemerintahan.

Pasal 44

Setiap orang baik sendiri maupun bersamasama berhak mengajukan pendapat, permohonan, pengaduan, dan atau usulan kepada pemerintah dalam rangka pelaksanaan pemerintahan yang bersih, efektif, dan efisien, baik dengan lisan maupun dengan tulisan, sesuai dengan ketentuan peraturan perundangundangan.

Dengan adanya pasal-pasal tersebut diatas tidak ada keberpihakan di dalam pemerintahan, baik pria maupun wanita memiliki kesempatan yang sama di dalam pemerintahan khususnya memiliki peluang yang sama untu dapat menjadi leader (pemimpin) di dalam pemerintahan sebagai bagian dari apa yang dinamakan Birokrasi. Namun meskipun berbagai peraturan telah mengatur mengenai masalah-masalah gender, kondisi dinamis gender di Indonesia saat ini masih menunjukkan bahwa kualitas perempuan masih jauh tertinggal dari laki-laki.

Gender Management System adalah suatu pendekatan pada pengarus utamaan gender, yang merupakan jaringan terpadu dari struktur, mekanis dan proses yang dijadikan kedalam satu alur berpikir untuk menuntun, merencanakan, dan mengevalusi proses (apakah itu didalam membuat suatu kebijakan-kebijakan atau program-program) dari pengarusutamaan gender atau gender mainstreaming kedalam seluruh area kerja organisasi. Pendekatan secara holistik diperlukan karena akan membuat pemerintah dan lembaga non pemerintah memiliki pemahaman bahwa kekerasan terhadap perempuan sebagai masalah sosial dan masalah yang rumit dimana pemerintah berkewajiban merespon dengan kebijakan yang tepat, perencanaan, implementasi dan sumber daya yang cukup (Mochtar et al., 2013). Atau secara umum kondisi kualitas Sumber Daya Manusia (SDM) khususnya perempuan masih rendah. Hal ini dapat di lihat dari kondisi perempuan pada berbagai bidang kehidupan.

\section{Kesimpulan}

Di Indonesia, ditetapkan sebagai laki-laki adalah kepala keluarga dan pencari nafkah utama, perempuan adalah ibu rumah tangga dan tugas utamanya adalah mendidik dan mengasuh anak. Konsekuensi dari ketentuan pembagian seperti tersebut di atas adalah, bahwa peran perempuan adalah di ranah domestik, peran gender laki-laki adalah di wilayah publik. Hal tersebut maka terciptalah suatu sistem ketidakadilan gender yang kemudian diterima meluas, dianggap sesuatu yang biasa, dan tidak lagi dirasakan sebagai sesuatu 
yang salah. Selain itu dalam hal kepemimpinan dalam birokrasi lebih banyak di dominasi oleh lakilaki maka perumusan kebijakannya nantinya pun akan sesuai dengan kondisi dan pemikiran lakilaki, lalu apakah mereka akan memikirkan ranahranah kepentingan wanita, misalnya saja mengenai AKI (Angka Kematian Ibu), Kesehatan Reproduksi Wanita, Program KB (Keluarga Berencana) dikaitkan dengan kawin muda yang saat ini marak terjadi di Indonesia.

Peraturan yang mengatur masalah hak perempuan yang diberlakukan di Indonesia harus ditegakkan bukan hanya sebatas aturan tertulis saja namun juga dijadikan law in action. Adanya sinergitas antara Lembaga,Badan, yang terkait dengan kewanitaan dalam hal meningkatkan keterwujudan turut sertanya wanita dalam berbagai aspek sosial di Indonesia khususnya keikutsertaan wanita untuk maju menjadi pemimpin dalam suatu Birokrasi.

\section{DAFTAR PUSTAKA}

Dwiyanto, Agus, et.al. 2006. Reformasi Birokrasi Publik di Indonesia. Gajah Mada University Press.Yogyakarta.

Fakih, Mansour. 2007. Analisis Gender dan Transformasi Sosial. Pustaka Pelajar. Yogyakarta.

Ihromni, Tapi Omas., Irianto, Sulistyowati dan Achie Sudiarti. 2000. Penghapusan DiskriminasiTerhadap Wanita. Alumni. Bandung.

Mochtar, H., Indrayanti, K. W. dan Ristanty, E. 2013. Kajian Penerapan Prinsip- Prinsip Gender Management System (Gms) untuk Memerangi Kekerasan Terhadap Perempuan Di Wilayah Malang Raya. Jurnal Cakrawala Hukum. 18(1), 7285.
Mu'awanah, Elfi dan Hidayah, Rifa. 2006. Menuju Kesetaraan Gender. Kutub Minar, Malang. Raja Grafindo Persada. Jakarta.

Nurita, R. F. 2015. Kajian Filsafat Hukum Tentang Demokrasi Di Indonesia. Jurnal Cakrawala Hukum, 6(1), 89-98.

Nurtjahjo, Hendra. 2006. Filsafat Demokrasi, Bumi Aksara. The Politic. Jakarta.

Riniwati, Harsuko. 2011. Mendongkrak Motivasi dan Kinerja Pendekatan Pemberdayaan SDM. UB Press Malang.

Sihite, Romany. 2007. Perempuan,Kesetaraan, dan Keadilan:Suatu Tinjauan Berwawasan, Raja Grafindo, Jakarta.

Undang-Undang Dasar Negara Republik Indonesia Tahun 1945.

Undang-Undang Republik Indonesia Nomor 39 Tahun 1999 Tentang Hak Asasi Manusia.

Undang-Undang Republik Indonesia Nomor 7 Tahun 1984 Tentang Pengesahan Konvensi Mengenai Penghapusan Segala Bentuk Diskriminasi Terhadap Wanita.

Wahid, Abdul dan Muhibbin, Moh. 2009. Etika Profesi Hukum Rekonstruksi Citra Peradilan di Indonesia. Bayu Media. Malang.

\section{How to cite:}

Nurita, R. F. 2017. Kajian Hukum Terhadap Representasi Kepemimpinan Wanita Sebagai Wujud Birokrasi yang Profesional. Jurnal Cakrawala Hukum, 8(2). 